\title{
Pengaruh Komunikasi Internal dan Koordinasi Terhadap Efektivitas Kerja pada Pegawai Rumah Sakit Prasetya Bunda Tasikmalaya
}

\author{
Yuyun Rachmayuniawati \\ Universitas Nasional Pasim \\ Email: yuyun.rachmayuniawati@gmail.com
}

\author{
ARTICLE INFO \\ Article History: \\ Received 10 August 2018 \\ Revised 1 September 2018 \\ Accepted 15 September \\ 2018
}

\section{JEL Classification: \\ E24, J80, J81}

Kata kunci:

Komunikasi Internal, Koordinasi, dan

Efektivitas Kerja Pegawai

\begin{abstract}
Abstrak
Penelitian ini bertujuan untuk mengetahui: (1) Komunikasi, koordinasi, dan efektivitas kerja pegawai; (2) Pengaruh komunikasi terhadap efektivitas kerja pegawai pada Rumah Sakit Prasetya Bunda Tasikmalaya; (3) Pengaruh koordinasi terhadap efektivitas kerja pegawai pada Rumah Sakit Prasetya Bunda Tasikmalaya; (4) Pengaruh komunikasi dan koordinasi secara bersama-sama terhadap efektivitas kerja pegawai pada Rumah Sakit Prasetya Bunda Tasikmalaya. Untuk mengukur variabel komunikasi digunakan angket penelitian komunikasi yang menyangkut komunikasi internal ke bawah, komunikasi internal ke atas, dan komunikasi internal horizontal. Sedangkan untuk mengukur variabel koordinasi digunakan angket koordinasi menyangkut aspek koordinasi vertikal dan horizontal. Selanjutnya angket efektivitas kerja pegawai terdiri dari kemampuan menyesuaikan diri, prestasi kerja dan kepuasan kerja. Sebagai unit analisis dari penelitian ini adalah Pegawai Rumah Sakit Prasetya Bunda Tasikmalaya yang terdiri dari tenaga medis dan non medis sebanyak 82 orang yang merupakan sampel terpilih. Waktu pengambilan data adalah tahun 2018 dan metode analisis yang digunakan adalah menggunakan analisis jalur. Berdasarkan hasil analisis deskriptif terhadap variabel komunikasi $\left(X_{1}\right)$ pada Rumah Sakit Prasetya Bunda Tasikmalaya sudah cukup baik. Berdasarkan hasil analisis deskriptif terhadap variabel koordinasi $\left(\mathrm{X}_{2}\right)$ pada Rumah Sakit Prasetya Bunda Tasikmalaya sudah cukup baik. Berdasarkan hasil analisis deskriptif terhadap variabel efektivitas kerja pegawai (Y) pada Rumah Sakit Prasetya Bunda Tasikmalaya sudah cukup baik. Hasil dari penelitian ini menunjukkan bahwa secara bersama-sama kedua variabel bebas komunikasi dan koordinasi memberikan pengaruh terhadap efektivitas kerja pegawai sebesar $50,8 \%$. Adapun sisanya sebesar 49,2\% disebabkan oleh variabel-variabel lain diluar kedua variabel tersebut yang tidak dilibatkan dalam penelitian ini.
\end{abstract}




\section{PENDAHULUAN}

Penyelenggaraan program kesehatan di Indonesia sangat luas dan kompleks. Kondisi ini tentunya perlu dukungan berbagai sumber daya serta sistem pengelolaan secara profesional dengan harapan berbagai kompleksitas permasalahan yang dihadapi dapat diatasi dengan baik. Kompleksitas permasalahan pelayanan kesehatan pada umumnya didominasi oleh faktor lingkungan eksternal yang sangat dinamis. Implikasi dari kompleksitas permasalahan kesehatan tentunya menjadi tantangan yang harus disikapi dengan bijak serta dihadapi secara profesional oleh institusi kesehatan,

Paradigma baru program kesehatan dewasa ini telah berkembang, yaitu upaya pelayanan kesehatan yang semula hanya terbatas dalam penyembuhan, kini telah berkembang menjadi suatu kesatuan upaya kesehatan masyarakat secara menyeluruh. Untuk merealisasikan program tersebut, peran serta aktif masyarakat sangat diperlukan yaitu meliputi upaya-upaya peningkatan, pencegahan, penyembuhan serta pemulihan secara terpadu, komprehensif dan berkesinambungan.

Untuk mengantisipasi perubahan eksternal dan dinamika organisasi serta budaya masyarakat yang sangat dinamis, kompetensi sumber daya manusia di setiap organisasi dituntut untuk selalu belajar dan mengembangkan potensi diri agar mampu mengantisipasi berbagai kemungkinan atau tantangan - tantangan di masa yang akan datang. Secara organisasi, relevansi berbagai konsep strategi perlu didisain secara komprehensif, fleksibel serta didukung dengan sumber daya secara tepat guna dan efisien, dengan harapan visi dan misi organisasi dapat terealisasi secara efektif dan dapat menjamin kotinuitas lembaga.

Rumah sakit sebagai salah satu institusi pelayanan kesehatan masyarakat memiliki peranan strategis dalam upaya merealisasikan program pembangunan nasional menuju masyarakat yang sejahtera. Program kesehatan masyarakat yang dilakukan institusi rumah sakit kini telah berkembang. Pada awalnya peranan rumah sakit terbatas dalam upaya penyembuhan dan pemulihan. Namun dewasa ini dengan perubahan orientasi, nilai dan pemikiran yang berkembang sejalan dengan perkembangan ilmu pengetahuan dan sosial budaya masyarakat, rumah sakit juga melaksanakan upaya peningkatan dan pencegahan secara terpadu.

Dalam upaya mengoptimalisasikan peran dan fungsi rumah sakit diperlukan dukungan sumber daya manusia yang memiliki komitmen tinggi terhadap pencapaian visi dan misi rumah sakit. Dalam hal ini, salah satu aspek yang penting diperhatikan terkait dengan peranan sumber daya manusia dalam institusi rumah sakit adalah sejauh mana program kerja rumah sakit mampu mendorong para pegawai menunjukan efektifitas kerja yang optimal. Efektivitas kerja pegawai Menurut Sutarto (2012:38) adalah suatu keadaan dimana aktifitas jasmaniah dan rohaniah yang dilakukan oleh manusia dapat mencapai hasil akibat sesuai yang dikehendaki.

Keberhasilan dan efektivitas kerja seseorang dalam suatu bidang pekerjaan banyak ditentukan oleh tingkat kompetensi, profesionalisme juga komitmen terhadap bidang yang ditekuninya. Suatu komitmen organisasional menunjukkan suatu daya dari sesorang dalam mengidentifikasikan keterlibatan dalam suatu organisasi. Oleh karena itu komitmen organisasional akan menimbulkan rasa ikut memiliki (sense of belonging) bagi pekerja terhadap organisasi. Terjadinya perubahan-perubahan dalam organisasi juga mempunyai dampak pada terjadinya perubahan dalam tugas dan kewajiban pegawai. Para pegawai diharapkan menjadi lebih kreatif mencari cara baru untuk memperbaiki efektivitas dan efisiensi kerja di organisasi. Ketika organisasi mengurangi jumlah pegawai, organisasi itu akan lebih tergantung pada pegawai yang tetap tinggal untuk melakukan hal-hal melebihi apa yang ditugaskan kepada mereka. 
Rumah Sakit Prasetya Bunda Tasikmalaya adalah salah satu rumah sakit swasta yang berada di Kota Tasikmalaya yang awalnya merupakan Rumah Sakit Ibu dan Anak. Salah satu faktor yang dapat mendukung pencapaian efektivitas kerja pegawai adalah aspek komunikasi internal. Pada sebuah organisasi khususnya rumah sakit, proses komunikasi internal adalah proses yang pasti dan selalu terjadi. Komunikasi internal adalah sarana untuk mengadakan koordinasi antara berbagai sub bagian dalam organisasi. Organisasi yang berfungsi baik, ditandai oleh adanya kerjasama secara sinergis dan harmonis dari berbagai komponen. Sikap ini ditunjukkan oleh pegawai sebagai salah satu perhatiannya terhadap kebiasaan-kebiasaan yang berjalan pada organisasi tersebut. Hal ini merupakan salah satu cara pegawai untuk lebih menunjukan prestasinya.

Beberapa fenomena yang berkaitan dengan komunikasi salah satunya ditandai dengan adanya keluhan dari pasien mengenai informasi tentang rumah sakit dikarenakan kurang berjalannya komunikasi internal antar pegawai. Fenomena dapat dilihat pada tabel 1.

Tabel 1. Jumlah Keluhan Pasien Rumah Sakit Prasetya Bunda Tasikmalaya Periode Tahun 2016-2017

\begin{tabular}{c|c|c|c}
\hline Tahun & $\begin{array}{c}\text { Jumlah } \\
\text { pasien }\end{array}$ & Keluhan & Persentase \\
\hline 2016 & 5842 & 58 & 0,99 \\
\hline 2017 & 5349 & 87 & 1,63 \\
\hline
\end{tabular}

Sumber: Rumah Sakit Prasetya Bunda Tasikmalaya, 2018

Pada tabel 1 dapat dilihat pada tahun 2016 terdapat keluhan pasien sebanyak 0,99\% dan pada tahun 2017 naik menjadi 1,63\% dikarenakan kurang baiknya komunikasi para pegawai (medis atau non medis) misalnya tidak samanya informasi mengenai pelayanan di rumah sakit yang mengakibatkan pasien tidak menerima informasi yang jelas dan akhirnya pasien melakukan keluhan kepada pihak rumah sakit.
Fenomena yang berkaitan dengan koordinasi pada Rumah Sakit Prasetya Bunda dapat diketahui melalui absensi pegawai periode September 2016 sampai dengan Desember 2017 berikut ini:

Tabel 2. Pelaksanaan Rapat Koordinasi Rumah Sakit Prasetya Bunda Tasikmalaya Periode Tahun 2016 - 2017

\begin{tabular}{c|c|c|c}
\hline Tahun & Target & Terlaksana & $\begin{array}{c}\text { Tidak } \\
\text { Terlaksana }\end{array}$ \\
\hline 2016 & 24 kali & 22 & 2 \\
\hline 2017 & 24 Kali & 15 & 9 \\
\hline
\end{tabular}

Sumber: Rumah Sakit Prasetya Bunda Tasikmalaya, 2018

Pada tabel di atas, dapat terlihat bahwa rapat koordinasi yang seharusnya dilaksanakan sebanyak dua kali dalam satu bulan untuk tahun 2015 terlaksana sebanyak 22 kali dikarenakan faktor pemimpin yang kurang tegas dalam menerapkan rutinitas rapat koordinasi dengan bawahan. Namun untuk tahun 2016 rapat koordinasi kerja semakin menurun hanya terlaksana sebanyak 15 kali dalam satu tahun. Hal tersebut dapat menjadikan efektivitas kerja pegawai semakin menurun karena dengan tidak adanya koordinasi yang jelas di perusahaan target kerja sulit untuk dicapai.

Fenomena yang berkaitan dengan efektivitas kerja pada Rumah Sakit Prasetya Bunda Tasikmalaya periode 2016 s/d 2017 sebagai berikut:

Tabel 3. Hasil Kegiatan Rawat Inap

\begin{tabular}{c|l|r|r|r}
\hline NO & \multicolumn{1}{|c|}{ URAIAN } & SATUAN & $\mathbf{2 0 1 6}$ & $\mathbf{2 0 1 7}$ \\
\hline 1. & $\begin{array}{l}\text { Rata-rata tempat } \\
\text { tidur siap pakai }\end{array}$ & Buah & 52 & 52 \\
\hline 2. & $\begin{array}{l}\text { Jumlah hari } \\
\text { perawatan }\end{array}$ & Hari & 4627 & 6290 \\
\hline 3. & $\begin{array}{l}\text { Jumlah lama } \\
\text { dirawat }\end{array}$ & Hari & 4627 & 6290 \\
\hline 4. & $\begin{array}{l}\text { Jumlah } \\
\text { penderita keluar }\end{array}$ & Orang & 1088 & 1499 \\
\hline
\end{tabular}




\begin{tabular}{c|l|r|r|r}
\hline 5. & $\begin{array}{l}\text { Jumlah } \\
\text { penderita keluar } \\
\text { per tempat } \\
\text { tidur }\end{array}$ & Orang & 13 & 17 \\
\hline 6. & $\begin{array}{l}\text { Rata-rata lama } \\
\text { dirawat }\end{array}$ & Hari & 4 & 4 \\
\hline 7. & $\begin{array}{l}\text { Rata-rata } \\
\text { tempat tidur } \\
\text { kosong }\end{array}$ & Hari & 13 & 8 \\
\hline 8. & $\begin{array}{l}\text { B O R / Bed } \\
\text { Occupation Rate }\end{array}$ & $\begin{array}{r}\text { Persent } \\
\text { ase }\end{array}$ & 24,7 & 33,6 \\
\hline 9. & $\begin{array}{l}\text { Frekuensi } \\
\text { pemakaian tempa } \\
\text { tidur }\end{array}$ & Kali & 20,9 & 28,8 \\
\hline
\end{tabular}

Sumber : Rumah Sakit Prasetya Bunda Tasikmalaya, 2018

Jumlah tingkat hunian rumah sakit tahun ini bila dibandingkan dengan tahun lalu dengan rata-rata lama dirawat berkisar antara 4 sampai dengan 5 hari dan interval tempat tidur kosong menurun dari 12,9 hari menjadi 8,2 hari, dalam satu tahun tempat tidur terisi rata-rata 17 orang dengan masing-masing tempat tidur dalam satu tahun digunakan sebanyak 28 kali.

Maksud dari penelitian ini adalah untuk mengetahui:

1. Komunikasi internal pada Rumah Sakit Prasetya Bunda Tasikmalaya.

2. Koordinasi pada Rumah Sakit Prasetya Bunda Tasikmalaya.

3. Efektivitas kerja pegawai pada Rumah Sakit Prasetya Bunda Tasikmalaya.

4. Besar pengaruh komunikasi internal terhadap efektivitas kerja pegawai pada Rumah Sakit Prasetya Bunda Tasikmalaya.

5. Besar pengaruh koordinasi terhadap efektivitas kerja pegawai pada Rumah Sakit Prasetya Bunda Tasikmalaya.

6. Besar pengaruh komunikasi internal dan koordinasi terhadap efektivitas kerja pegawai secara simultan pada Rumah Sakit Prasetya Bunda Tasikmalaya

\section{KAJIAN PUSTAKA}

1. Manajemen Sumber Daya Manusia

Samsudin (2010) menyatakan bahwa manajemen sumber daya manusia merupakan suatu kegiatan pengelolaan yang meliputi pendayagunaan, pengembangan, penilaian, pemberian balas jasa bagi manusia sebagai individu anggota organisasi atau perusahaan bisnis. Sedangkan menurut Handoko (2011) Manajemen Sumber Daya Manusia adalah penarikan, seleksi, pengembangan, pemeliharaan, dan penggunaan sumber daya untuk mencapai baik tujuan-tujuan individu maupun organisasi. Dari beberapa pendapat di atas dapat ditarik kesimpulan bahwa manajemen sumber daya manusia merupakan ilmu dan seni yang didalamnya terkandung fungsi fungsi manajerial dan operasional yang ditujukan agar sumber daya manusia dapat dimanfaatkan seefektif dan efisien mungkin untuk mencapai sasaran yang ditetapkan.

\section{Komunikasi Internal}

Pengertian komunikasi dari pakar berbeda. Untuk orang-orang awam sering mengidentifikasikan komunikasi sebagai alat atau media pengirim pesan dan informasi seperti: televisi, radio, telegram dan lain-lain.

Hidayat (2012) menyatakan bahwa komunikasi adalah usaha untuk membangun sebuah kebersamaan yang dilandasi oleh persamaan persepsi tentang sesuatu sehingga mendorong diantara pelaku komunikasi untuk saling memahami sesuai dengan keinginan atau tujua bersama. Sedangkan menurut Djamarah (2014), komunikasi dapat didefinisikan sebagai suatu proses pertukaran informasi yang dilakukan oleh dua orang atau lebih yang akan saling memberikan pengertian yang mendalam.

Menurut Komala (2009) komunikasi adalah suatu proses pertukaran informasi 
yang dilakukan oleh dua orang atau lebih yang akan saling memberikan pengertian yang mendalam. Dari ketiga definisi di atas memberikan pemahaman bahwa yang dimaksud dengan komunikasi adalah proses penyampaian informasi dari seseorang (sender) kepada orang lain (receiver) melalui sistem media tertentu yang biasa dilakukan (yang lazimnya dilakukan), bisa menggunakan simbolsimbol, sinyal-sinyal tertentu maupun perilaku atau tindakan sehingga informasi dapat dipahami oleh penerima pesan (receiver) dan adanya feedback penerima pesan (receiver) kepada pengirim pesan (sender).

\section{Koordinasi}

Dalam sebuah organisasi setiap pimpinan perlu untuk mengkoordinasikan kegiatan kepada anggota organisasi yang diberikan dalam menyelesaikan tugas. Dengan adanya penyampaian informasi yang jelas, pengkomunikasian yang tepat, dan pembagian pekerjaan kepada para bawahan oleh manajer maka setiap individu bawahan akan mengerjakan pekerjaannya sesuai dengan wewenang yang diterima. Tanpa adanya koordinasi setiap pekerjaan dari individu karyawan maka tujuan perusahaan tidak akan tercapai.

Koordinasi menurut Awaluddin Djamin dalam Hasibuan (2011) diartikan sebagai suatu usaha kerja sama antara badan, instansi, unit dalam pelaksanaan tugas-tugas tertentu, sehingga terdapat saling mengisi, saling membantu dan saling melengkapi. Dengan demikian koordinasi dapat diartikan sebagai suatu usaha yang mampu menyelaraskan pelaksanaan tugas maupun kegiatan dalam suatu organisasi. Menurut Leonard D. White dalam Inu Kencana (2011) Koordinasi adalah penyesuaian diri dari masing-masing bagian, dan usaha menggerrakkan serta mengoperasikan bagian-bagian pada waktu yang cocok, sehingga dengan demikian masing-masing bagian dapat memberikan sumbangan terbanyak pada keseluruhan hasil.

Menurut tinjauan manajemen, koordinasi meliputi :

1. Jumlah usaha baik secara kuantitatif, maupun secara kualitatif.

2. Waktu yang tepat dari usaha-usaha tersebut.

3. Directing atau penentuan arah usahausaha tersebut.

Berdasarkan defenisi di atas maka dapat disebutkan bahwa koordinasi memiliki syarat-syarat yakni:

1. Sense of Cooperation, perasaan untuk saling bekerja sama, dilihat per bagian.

2. Rivalry, dalam organisasi besar, sering diadakan persaingan antar bagian, agar saling berlomba.

3. Team Spirit, satu sama lain per bagian harus saling menghargai.

4. Esprit de Corps, bagian yang saling menghargai akan makin bersemangat.

Selanjutnya koordinasi memiliki sifat-sifat sebagai berikut :

1. Koordinasi adalah dinamis, bukan statis.

2. Koordinasi menekankan pandangan menyeluruh oleh seorang manajer dalam kerangka mencapai sasaran.

3. Koordinasi hanya meninjau suatu pekerjaan secara keseluruhan.

\section{Efektivitas Kerja}

Efektivitas kerja terdiri dari dua
kata yaitu efektivitas dan
kerja. Efektivitas kerja pegawai
menurut Sutarto (2012) adalah suatu
keadaan dimana aktifitas jasmaniah
dan rohaniah yang dilakukan oleh
manusia dapat mencapai hasil akibat
sesuai yang dikehendaki. Suatu
pekerjaan dikatakan efektif jika suatu
pekerjaan dapat diselesaikan tepat
pada waktunya sesuai dengan rencana
yang telah ditetapkan.


Efektivitas kerja merupakan suatu keadaan tercapainya tujuan yang diharapkan atau dikehendaki melalui penyelesaian pekerjaan sesuai dengan rencana yang telah ditentukan. Adapun pengertian efektivitas menurut para ahli diantaranya sebagai berikut: Siagian (2011) menyatakan efektivitas adalah pemanfaatan sumber daya, sarana dan prasarana dalam jumlah tertentu yang secara sadar ditetapkan sebelumnya untuk menghasilkan sejumlah barang atas jasa kegiatan yang dijalankan. Efektivitas menunjukkan keberhasilan dari segi tercapai tidaknya sasaran yang telah ditetapkan.

Jika hasil kegiatan semakin mendekati sasaran berarti makin tinggi efektivitasnya. Apabila dicermati bahwa efektivitas kerja pada suatu organisasi baik swasta maupun pemerintah maka sasarannya tertuju pada proses pelaksanaan dan tingkat keberhasilan kegiatan yang dilakukan oleh para pegawai itu sendiri. Kegiatan yang dimaksud adalah usaha yang dapat memberikan manfaat yang sebesar-besarnya bagi organisasi tersebut. Istilah efektif dan efisien merupakan istilah yang saling berkaitan dan patut dihayati dalam upaya untuk mencapai tujuan suatu organisasi.

Pada prinsipnya efektivitas individu para anggotanya di dalam melaksanakan tugas sesuai dengan kedudukan dan peran mereka masingmasing dalam organisasi tersebut.

Dari pendapat para ahli di atas, dapat disimpulkan bahwa suatu pekerjaan dapat dilaksanakan secara tepat, efektif, dan efisien apabila pekerjaan tersebut dilaksanakan dengan tepat sesuai dengan yang telah direncanakan, maka jelas bahwa sesungguhnya efektivitas kerja tidak lain adalah seorang atau beberapa orang khususnya pegawai dalam satu unit organisasi atau perusahaan untuk dapat melaksanakan tujuan yang dicapai dalam suatu sistem yang ditentukan dengan suatu pandangan untuk memenuhi kebutuhan sistem itu sendiri. Berdasarkan pendapatpendapat di atas juga, dapat disimpulkan bahwa efektivitas adalah kemampuan seseorang atau beberapa orang yang terdapat dalam suatu kelompok ataupun organisasi untuk dapat melahirkan suatu kegunaan atau manfaat dari apa yang dikerjakan.

\section{Pengaruh Komunikasi Internal dan Koordinasi terhadap Efektivitas Kerja}

Komunikasi kerja memiliki pengaruh terhadap efektivitas kerja pegawai sebagaimana yang diungkapkan Hidayat (2013) bahwa komunikasi kerja memiliki pengaruh yang positif dan signifikan terhadap efektivitas kerja pegawai. Komunikasi membantu perkembangan motivasi dengan menjelaskan kepada para karyawan apa yang harus dilakukan, bagaimana mereka bekerja baik dan apa yang dapat dikerjakan untuk memperbaiki kinerja jika di bawah standar. Selanjutnya penelitian tentang komunikasi internal berpengaruh terhadap efektivitas kerja pegawai sebagaimana yang diungkapkan Manopo (2014) bahwa komunikasi berpengaruh positif terhadap efektivitas kerja pegawai.

Komunikasi harus terselenggara dengan baik dan efektif. Komunikasi dapat dikatakan berjalan baik dan efektif apabila setiap anggota memperoleh keteranganketerangan yang jelas dalam melaksanakan pekerjaannya. Lewat komunikasi rasa ingin tahu dapat tersalurkan, hal ini mampu mendorong semangat kerja. Selain itu komunikasi juga membantu menyatukan anggota organsisasi untuk bekerja sama. Oleh karena itu komunikasi mutlak 
diperlukan demi tercapainya tujuan organisasi. (Manopo: 2014).

\section{METODE PENELITIAN}

\section{Desain Penelitian}

Menurut Sangadji dan Sopiah (2010) desain penelitian adalah rancangan utama penelitian yang menyatakan metode-metode dan prosedur-prosedur yang digunakan oleh peneliti dalam pemilihan, pengumpulan dan analisis data. Desain penelitian yang digunakan dalam penelitian ini adalah desain asosiatif. Menurut Sugiyono (2010), desain asosiatif berguna untuk menganalisis hubungan antara satu variabel dengan variabel lainnya atau bagaimana suatu variabel mempengaruhi variabel lain. Metode penelitian dirancang melalui langkah - langkah penelitian dari operasional variabel, penentuan jenis dan sumber data, metode pengumpulan data dan diakhiri dengan rancangan pengujian hipotesis dan statistik.

Langkah-langkah desain penelitian tersebut dapat diuraikan sebagai berikut:

1. Menetapkan permasalahan sebagai indikasi dari fenomena penelitian, selanjutnya menetapkan judul penelitian.

2. Mengidentifikasi permasalahan yang terjadi.

3. Menetapkan rumusan masalah.

4. Menetapkan tujuan penelitian.

5. Menetapkan hipotesis penelitian, berdasarkan fenomena dan dukungan teori.

6. Menetapkan konsep variabel penelitian yang digunakan.
7. Menetapkan sumber data, teknik penentuan sampel dan teknik pengumpulan data.

8. Melakukan analisis data.

9. Melakukan pelaporan hasil penelitian.

\section{Unit Analisis}

Menurut Soedibjo (2013), unit analisis adalah unit yang akan digunakan untuk menjelaskan atau menggambarkan karakteristik dari kumpulan objek yang lebih besar lagi. Karena penelitian ini bertujuan untuk meneliti komunikasi internal, koordinasi, dan efektivitas kerja pegawai pada Rumah Sakit Prasetya Bunda Tasikmalaya, maka unit analisisnya adalah pegawai pada Rumah Sakit Prasetya Bunda Tasikmalaya.

\section{Data dan Sumber Data}

Menurut Moleong (2014) mengatakan bahwa sumber data utama dalam penelitian kualitatif adalah kata-kata, dan tindakan selebihnya adalah data tambahan seperti dokumen dan lain-lain. Adapun sumber data yang digunakan dalam penelitian ini adalah sumber data primer. Sumber data primer diperoleh secara langsung atau pertama kali dari sumber utama. Data ini meliputi jawaban atas pertanyaan dalam kuesioner yang diajukan pada responden dan hasil wawancara pada tahun 2018.

\section{Operasionalisasi Variabel}

Operasionalisasi variabel dalam penelitian ini dapat diuraikan sebagai berikut:

Tabel 4. Operasionalisasi Variabel dalam Penelitian

\begin{tabular}{l|l|l|c}
\hline \multicolumn{1}{c|}{ Variabel } & \multicolumn{1}{c|}{ Dimensi } & \multicolumn{1}{|c}{ Indikator } & \multicolumn{1}{c}{ Skala } \\
\hline $\begin{array}{l}\text { Komunikasi } \\
\text { Internal }\left(\mathbf{X}_{\mathbf{1}}\right)\end{array}$ & $\begin{array}{l}\text { 1. Komunikasi } \\
\text { Internal ke } \\
\text { bawah }\end{array}$ & $\begin{array}{l}\text { 1. Mpengirim pesan kepada } \\
\text { bawahan Ordinal }\end{array}$ & \\
$\begin{array}{l}\text { Usaha untuk } \\
\text { membangun }\end{array}$ & & $\begin{array}{l}\text { 2. Memberi arahan untuk } \\
\text { mencapai tujuan }\end{array}$ & \\
$\begin{array}{l}\text { sebuah } \\
\text { kebersamaan } \\
\text { yang dilandasi } \\
\text { oleh }\end{array}$ & & $\begin{array}{l}\text { 3. Kebijakan } \\
\text { 4. Memo }\end{array}$ & \\
& & $\begin{array}{l}\text { 1. Masukan } \\
\text { 2. Saran pengembangan }\end{array}$ & \\
\hline
\end{tabular}


Yuyun Rakhmawati: Pengaruh Komunikasi Internal...

\begin{tabular}{|c|c|c|c|}
\hline $\begin{array}{l}\text { persamaan } \\
\text { persepsi } \\
\text { tentang } \\
\text { sesuatu } \\
\text { sehingga } \\
\text { mendorong } \\
\text { diantara } \\
\text { pelaku } \\
\text { komunikasi } \\
\text { untuk saling } \\
\text { memahami } \\
\text { sesuai dengan } \\
\text { keinginan atau } \\
\text { tujua bersama } \\
\text { HIdayat (2012) }\end{array}$ & $\begin{array}{l}\text { 2. Komunikasi } \\
\text { Internal ke } \\
\text { atas }\end{array}$ & $\begin{array}{l}\text { 3. Audit } \\
\text { 1. Komunikasi sesama pegawai } \\
\text { 2. Memecahkan konflik } \\
\text { 3. Membuka jalan tercipta } \\
\text { hubungan bisnis } \\
\text { 4. Dukungan antar anggota } \\
\text { 1. Komunikasi beda bidang } \\
\text { 2. Tukar pikiran } \\
\text { 3. Usulan kepada anggota beda } \\
\text { bidang }\end{array}$ & \\
\hline $\begin{array}{l}\text { Koordinasi }\left(\mathbf{X}_{\mathbf{2}} \text { ) }\right. \\
\text { Suatu usaha } \\
\text { kerja sama } \\
\text { antara badan, } \\
\text { instansi, unit } \\
\text { dalam } \\
\text { pelaksanaan } \\
\text { tugas-tugas } \\
\text { tertentu, } \\
\text { sehingga } \\
\text { terdapat saling } \\
\text { mengisi, saling } \\
\text { membantu dan } \\
\text { saling } \\
\text { melengkapi. } \\
\text { Hasibuan } \\
\text { (2011) }\end{array}$ & $\begin{array}{l}\text { 1. Koordinasi } \\
\text { Vertikal } \\
\text { 2. Koordinasi } \\
\text { Horizontal }\end{array}$ & $\begin{array}{l}\text { 1. Rapat koordinasi dengan } \\
\text { pimpinan } \\
\text { 2. Pemahaman target kerja } \\
\text { 3. Alur koordinasi } \\
\text { 1. Kerjasama antar unit } \\
\text { 2. Penyelarasan visi dan misi } \\
\text { 3. Konsultasi dengan bagian lain }\end{array}$ & Ordinal \\
\hline $\begin{array}{l}\text { Efektivitas } \\
\text { Kerja }(Y) \\
\text { Suatu keadaan } \\
\text { dimana } \\
\text { aktifitas } \\
\text { jasmaniah dan } \\
\text { rohaniah yang } \\
\text { dilakukan oleh } \\
\text { manusia dapat } \\
\text { mencapai hasil } \\
\text { akibat sesuai } \\
\text { yang } \\
\text { dikehendaki. }\end{array}$ & $\begin{array}{l}\text { 1. Kemampuan } \\
\text { menyesuaikan } \\
\text { diri }\end{array}$ & $\begin{array}{l}\text { 1. Adaptasi dengan sistem kerja } \\
\text { baru } \\
\text { 2. Lebih dekat dengan rekan kerja } \\
\text { 3. Kerjasama } \\
\text { 1. Kecakapan kerja } \\
\text { 2. Tanggung jawab } \\
\text { 3. Bekerja sesuai perintah } \\
\text { 4. Target kerja } \\
\text { 1. Kepuasan terhada pekerjaan itu } \\
\text { 2. Kendiri } \\
\end{array}$ & Ordinal \\
\hline
\end{tabular}




\begin{tabular}{l|l|l|l}
\hline $\begin{array}{l}\text { Efektivitas } \\
\text { kerja Sutarto } \\
(2012: 38)\end{array}$ & $\begin{array}{l}\text { 3. Kesempatan promosi } \\
\text { 4. Kepuasan terhadap atasan }\end{array}$ \\
& 5. Kepuasan terhadap rekan kerja & \\
\hline
\end{tabular}

\section{Metode Analisis Data}

Dalam penelitian ini, analisis jalur (path analysis) digunakan untuk mengetahui hubungan sebab akibat, dengan tujuan menerangkan akibat langsung dan akibat tidak langsung seperangkat variabel, sebagai variabel penyebab terhadap variabel lainnya yang merupakan variabel akibat. Menurut Soedibjo (2013) bahwa salah satu alat yang sangat popular untuk penelitian adalah analisis path (path analysis) atau dikenal juga dengan analisis jalur. Dalam analisis jalur ini variabel yang dipengaruhi disebut variabel endogen dan variabel yang mempengaruhi disebut variabel eksogen. Dalam penelitian ini hubungan antara variabel, dapat digambarkan sebagai berikut:

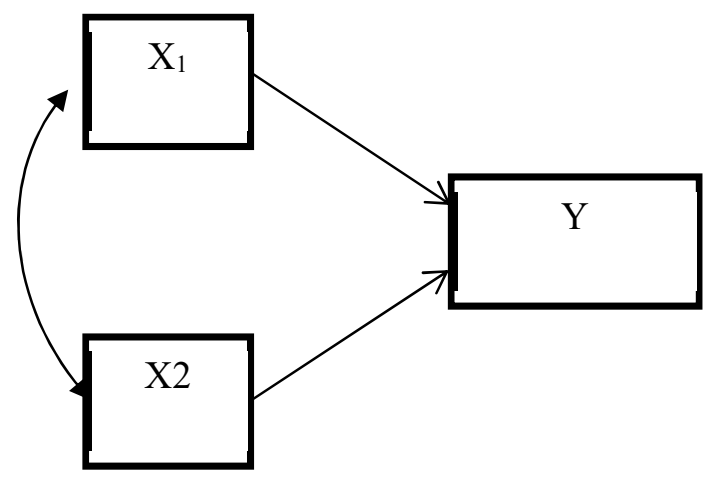

Gambar 1. Path Analysis (Model) dari $X_{1}, X_{2}$ ke $Y$

Keterangan:

$\mathrm{X} 1=$ Komunikasi Internal

$\mathrm{X} 2=$ Koordinasi

$\mathrm{Y}=$ Efektivitas Kerja Pegawai

Hubungan antara $X_{1}$ dan $X_{2}$ adalah hubungan korelasional. Intensitas keeratan hubungan tersebut dinyatakan oleh besarnya koefisien korelasi $r$ hubungan $X_{1}$ dan $X_{1}$ ke $Y$ adalah hubungan kausal. Besarnya pengaruh langsung dari $X_{1}$ ke $Y$ dan dari $X_{2}$ ke $Y$ masing-masing dinyatakan oleh besarnya nilai numerik koefisien jalur $p_{y \times 1}$ dan $p_{y \times 2}$

Rumus:

$p y 1 \times 2=\frac{\rho y 1 x 1-\rho y 1 \times 2 \rho y 1 \times 2}{1-\rho^{2} x 1 \times 2}$

$p y 1 x 1=\frac{\rho y 1 x 1-\rho y 1 x 2 \rho y 1 x 2}{1-\rho^{2} x 1 \times 2}$

\section{Keterangan :}

pyX1 = Pengaruh $\mathrm{X} 1$ terhadap $\mathrm{Y}$ pyX1 = Pengaruh $X 2$ terhadap $Y$

\section{HASIL DAN PEMBAHASAN}

Untuk mengetahui seberapa besar kontribusi variabel $X_{1}$ dan variabel $X_{2}$ (variabel independen) secara parsial terhadap variabel $Y$ (variabel dependen) adalah dengan melakukan pengujian SPSS yang hasilnya sebagai berikut: 
Tabel 5. Correlations

\begin{tabular}{|c|c|c|c|c|}
\hline & & $\mathrm{X} 1$ & $\mathrm{X} 2$ & $Y$ \\
\hline \multirow[t]{3}{*}{$\mathrm{X} 1$} & $\begin{array}{l}\text { Pearson } \\
\text { Correlation }\end{array}$ & 1 & $.281^{*}$ & $.409^{* *}$ \\
\hline & Sig. (2-tailed) & & .010 & .000 \\
\hline & $N$ & 82 & 82 & 82 \\
\hline \multirow[t]{3}{*}{$X 2$} & \begin{tabular}{|l} 
Pearson \\
Correlation
\end{tabular} & $.281^{*}$ & 1 & $.941^{* *}$ \\
\hline & Sig. (2-tailed) & .010 & & .000 \\
\hline & $N$ & 82 & 82 & 82 \\
\hline \multirow[t]{3}{*}{ Y } & \begin{tabular}{|l} 
Pearson \\
Correlation \\
\end{tabular} & $.409^{* *}$ & $.941^{* *}$ & \\
\hline & Sig. (2-tailed) & .000 & .000 & \\
\hline & $\mathrm{N}$ & 82 & 82 & 82 \\
\hline \multicolumn{4}{|c|}{$\begin{array}{l}\text { *. Correlation is significant at the } 0.05 \\
\text { level ( } 2 \text {-tailed). }\end{array}$} & \\
\hline \multicolumn{4}{|c|}{$\begin{array}{l}* * \text {. Correlation is significant at the } 0.01 \\
\text { level ( } 2 \text {-tailed). }\end{array}$} & \\
\hline
\end{tabular}

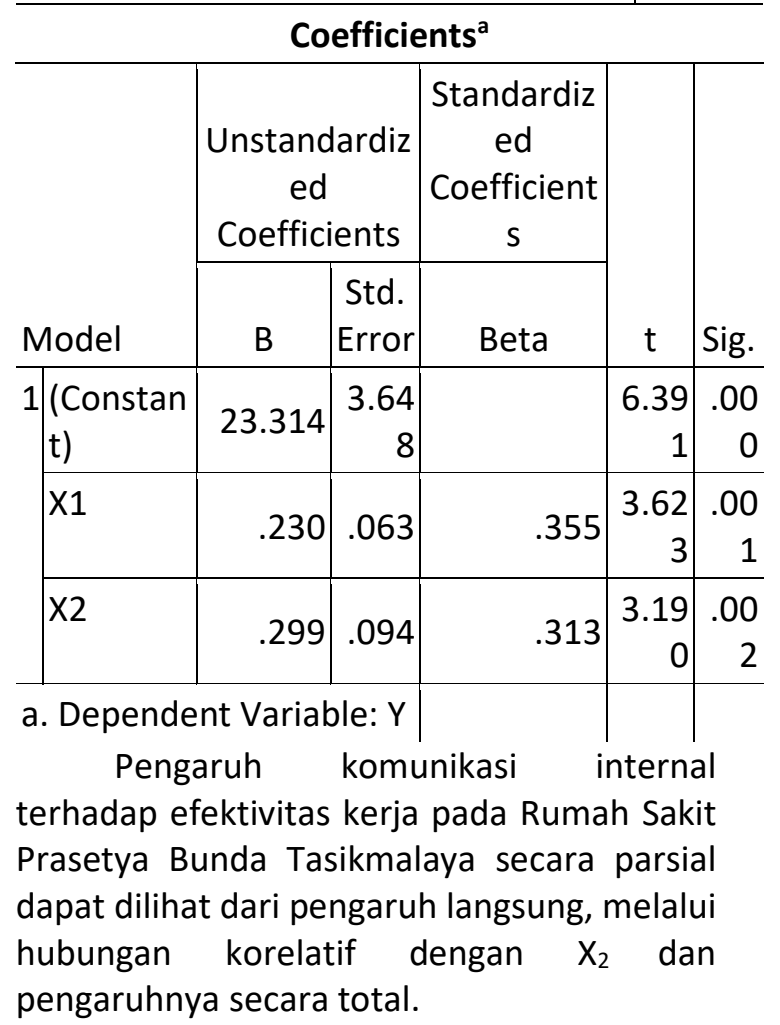

a. Pengaruh Langsung

$$
\begin{aligned}
& =P_{y \times 1} \times P_{y \times 1} \\
& =(0,355) \times(0,355)
\end{aligned}
$$

$$
=0,126
$$

b. Melalui hubungan korelatif dengan $\mathrm{X}_{2}$

$$
\begin{aligned}
& =P_{y \times 1} \times r_{x 1 \times 2} \times P_{y \times 2} \\
& =(0,150) \times(0,281) \times \\
& (0,313) \\
& =0,0225
\end{aligned}
$$

c. Pengaruh $X_{1}$ secara total

$=0,126+0,0225$

$=0,132$

Hasil ini menunjukkan bahwa besarnya pengaruh $X_{1}$ terhadap $Y$ secara total sebesar $13,2 \%$ (pembulatan). Pengujian hipotesis melalui hasil perhitungan SPSS pada tabel coeficients diperoleh angka $t$ penelitian sebesar 3,623 pada taraf signifikansi 0,05 dan Derajat Kebebasan (DK) dengan ketentuan : $\mathrm{DK}=\mathrm{n}-2$, atau 82-2 = 80. Dari ketentuan tersebut diperoleh angka $\mathrm{t}$ tabel sebesar 1,990. Dengan demikian dapat diambil kesimpulan bahwa angka t penelitian sebesat 3,623 > t tabel sebesar 1,990 sehingga HO ditolak dan $\mathrm{HI}$ diterima (hipotesis diterima).

\section{Pengaruh Koordinasi terhadap Efektivitas Kerja pada Rumah Sakit Prasetya Bunda Tasikmalaya \\ Pengaruh Koordinasi terhadap} efektivitas kerja pada Rumah Sakit Prasetya Bunda Tasikmalaya secara parsial dapat dilihat dari pengaruh langsung, melalui hubungan korelatif dengan $X_{1}$ dan pengaruhnya secara total.

a. Pengaruh Langsung

$$
\begin{aligned}
& =P_{y \times 2} \times P_{y \times 2} \\
& =(0,313) \times(0,313) \\
& =0,0979
\end{aligned}
$$

b. Melalui hubungan korelatif dengan $X_{1}$

$$
\begin{aligned}
& =P_{y \times 1} \times r_{x 1 \times 2} \times P_{y \times 2} \\
& =(0,355) \times(0,281) \times \\
& (0,313) \\
& =0,0312
\end{aligned}
$$




$$
\begin{aligned}
& \text { c. Pengaruh } \mathrm{X}_{2} \text { secara total } \\
& =0,0979+0,0312 \\
& =0,1291
\end{aligned}
$$

Hasil ini menunjukan bahwa besarnya pengaruh $X_{2}$ terhadap $Y$ secara total variabel $\mathrm{X}_{2}$ dapat menentukan perubahan dalam $\mathrm{Y}$ sebesar 12,91\% (pembulatan). Pengujian hipotesis melalui hasil perhitungan SPSS pada tabel coeficients diperoleh angka t penelitian sebesar 3,190 pada taraf signifikansi 0,05 dan Derajat Kebebasan (DK) dengan ketentuan : $\mathrm{DK}=\mathrm{n}-2$, atau 80-2 = 80. Dari ketentuan tersebut diperoleh angka $t$ tabel sebesar 1,990. Dengan demikian dapat diambil kesimpulan bahwa angka t penelitian sebesat $3,190>t$ tabel sebesar 1,990 sehingga $\mathrm{HO}$ ditolak dan $\mathrm{HI}$ diterima (hipotesis diterima).

Pengaruh Komunikasi Internal dan Koordinasi terhadap Efektivitas Kerja pada Rumah Sakit Prasetya Bunda Tasikmalaya

Untuk mengetahui seberapa besar persentase pengaruh kedua variabel $X$ (variabel independen) tersebut secara simultan terhadap variabel $\mathrm{Y}$ (variabel dependen) adalah dengan melakukan pengujian dengan koefisien determinasi $\left(\mathrm{R}^{2}\right)$ dengan melihat tabel Model Summary sebagai berikut:

Tabel 6. Model Summary

\begin{tabular}{l|r|r|r|c}
\hline \multicolumn{5}{c}{ Model Summary } \\
\hline $\begin{array}{l}\text { Mode } \\
\mathrm{I}\end{array}$ & $\mathrm{R}$ & $\begin{array}{c}\mathrm{R} \\
\text { Square }\end{array}$ & $\begin{array}{c}\text { Adjusted R } \\
\text { Square }\end{array}$ & $\begin{array}{c}\text { Std. Error } \\
\text { of the } \\
\text { Estimate }\end{array}$ \\
\hline 1 & $.510^{\mathrm{a}}$ & .261 & .244 & 6.71491 \\
\hline
\end{tabular}

a. Predictors: (Constant), VAR00002, VAR00001

Berdasarkan Model Summary di atas, maka besarnya pengaruh komunikasi internal dan koordinasi terhadap efektivitas kerja pegawai dapat dilihat dari $\mathrm{R}$ Square yaitu sebesar 0,261 atau 26,1\%. Hal ini dibuktikan juga dengan penambahan besarnya pengaruh $X_{1}$ dan $X_{2}$ secara bersama-sama terhadap $Y$ yaitu $13,2 \%+12,9 \%=26,1 \%$.

Persamaan path analisis kedua variabel independen yaitu komunikasi internal dan kepuasaan terhadap efektivitas kerja ditunjukkan pada tabel uji parsial (uji t) yang diambil dari nilai beta maka didapat nilai persamaan structural sebagai berikut :

$Y=0,355 X_{1}+0,313 X_{2}+\varepsilon$

Diagram jalur dari persamaan struktural di atas adalah sebagai berikut :

$\varepsilon$

0,739

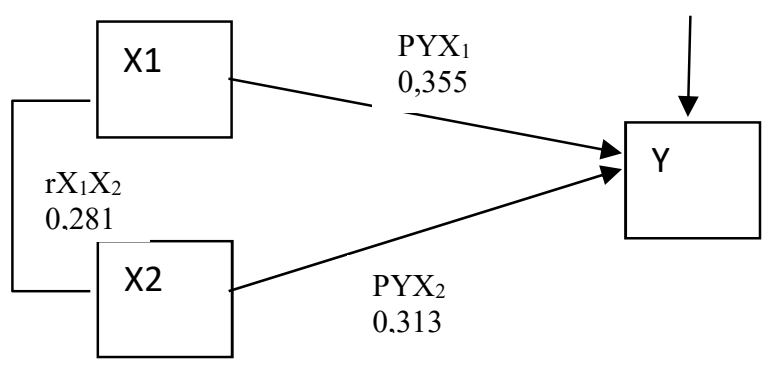

Gambar 2. Persamaan Struktural

Berdasarkan persamaan di atas dapat dijelaskan bahwa korelasi antara komunikasi internal (X1) dan kepuasan (X2) sebesar 0,281 , dan variabel komunikasi internal berpengaruh terhadap efektivitas kerja sebesar 0,355, kepuasan berpengaruh terhadap efektivitas kerja sebesar 0,313. Sedangkan variabel residu (gangguan) sebesar 0,739.

Untuk mengetahui apakah model di atas sudah benar atau tidak, maka diperlukan uji hipotesis. Uji hipotesis menggunakan angka $\mathrm{F}$ sebagaimana tertera dalam tabel di bawah ini: 
Yuyun Rakhmawati: Pengaruh Komunikasi Internal...

Tabel 7. Uji Hipotesis menggunakan Angaka $F$

\begin{tabular}{|c|c|c|c|c|c|}
\hline \multicolumn{6}{|c|}{ ANOVA $^{b}$} \\
\hline Model & $\begin{array}{l}\text { Sum of } \\
\text { Squares }\end{array}$ & $d f$ & $\begin{array}{l}\text { Mean } \\
\text { Square }\end{array}$ & $\mathrm{F}$ & Sig. \\
\hline 1 Regression & $\begin{array}{r}1267.89 \\
7 \\
\end{array}$ & 2 & $\begin{array}{r}633.94 \\
9 \\
\end{array}$ & $\begin{array}{r}14.06 \\
0 \\
\end{array}$ & $\begin{array}{r}.000 \\
\mathrm{a} \\
\end{array}$ \\
\hline Residual & $\begin{array}{r}3562.11 \\
5 \\
\end{array}$ & 79 & 45.090 & & \\
\hline Total & $\begin{array}{r}4830.01 \\
2 \\
\end{array}$ & 81 & & & \\
\hline \multicolumn{4}{|c|}{ a. Predictors: (Constant), X1, X2 } & & \\
\hline b. Dependent & Variable: & & & & \\
\hline
\end{tabular}

Pengujian dapat dilakukan dengan dua cara yaitu membandingkan besarnya angka $F$ penelitian dengan $\mathrm{F}$ tabel dan dengan cara membandingkan angka taraf signifikansi (sig) hasil perhitungan dengan taraf signifikansi 0,05 (5\%). Menghitung F penelitian dari SPSS yang diperoleh angka sebesar 14,060 kemudian menghitung $\mathrm{F}$ tabel dengan Derajat Kebebasan (DK) dengan ketentuan jumlah variabel -1 atau $3-1=2$, dan jumlah kasus - 2 atau $82-2=80$. Dengan ketentuan tersebut diperoleh angka $F$ tabel sebesar 3,00 . Sehingga $F$ penelitian sebesar 14,060 > $F$ tabel sebesar 3,00. Hal ini didukung dengan perhitungan angka signifikansi sebesar 0,000 $<0,005$. Dengan demikian, $\mathrm{HO}$ ditolak dan $\mathrm{HI}$ diterima (hipotesis diterima).

\section{PENUTUP}

\section{Kesimpulan}

Berdasarkan hasil analisis data penelitian dan uji hipotesis dapat diambil kesimpulan sebagai berikut :

1. Berdasarkan hasil analisis deskriptif terhadap variabel komunikasi $\left(\mathrm{X}_{1}\right)$ pada Rumah Sakit Prasetya Bunda Tasikmalaya sudah cukup baik dengan nilai 259,855 (dalam nilai jenjang interval $215-280$ ).

2. Berdasarkan hasil analisis deskriptif terhadap variabel koordinasi $\left(\mathrm{X}_{2}\right)$ pada Rumah Sakit Prasetya Bunda Tasikmalaya sudah cukup baik dengan nilai 257,5 (dalam nilai jenjang interval $215-280$ ).

3. Berdasarkan hasil analisis deskriptif terhadap variabel efektivitas kerja pegawai ( $\mathrm{Y}$ ) pada Rumah Sakit Prasetya Bunda Tasikmalaya sudah cukup baik dengan nilai 255 (dalam nilai jenjang interval 215 - 280).

4. Secara parsial komunikasi memberikan pengaruh yang signifikan terhadap efektivitas kerja pegawai pada Rumah Sakit Prasetya Bunda Tasikmalaya.

5. Secara parsial koordinasi memberikan pengaruh yang signifikan terhadap efektivitas kerja pegawai pada Rumah Sakit Prasetya Bunda Tasikmalaya.

6. Hasil analisis secara simultan menunjukan bahwa secara bersamasama kedua variabel bebas komunikasi dan koordinasi memberikan pengaruh terhadap efektivitas kerja pegawai sebesar $26,1 \%$. Adapun sisanya sebesar $73,9 \%$ disebabkan oleh variabel-variabel lain diluar kedua variabel tersebut yang tidak dilibatkan dalam penelitian ini.

\section{Saran}

Berdasarkan temuan yang diperoleh, saran dari penelitian ini adalah aspek-aspek yang penting dalam upaya meningkatkan efektivitas kerja pegawai melalui optimalisasi komunikasi dan lingkungan kerja, adalah sebagai berikut :

1. Rumah Sakit Prasetya Bunda Tasikmalaya harus lebih meningkatkan pentingnya komunikasi antarsesama personel Rumah Sakit.

2. Koordinasi kerja pegawai Rumah Sakit harus ditingkatkan.

3. Lebih sering diadakan rapat koordinasi

4. Pimpinan harus memiliki agenda pelatihan kerja rutin bagi karyawan

5. Rumah Sakit Prasetya Bunda Tasikmalaya dalam meningkatkan efektivitas kerja pegawai perlu disertai pelatihan-pelatihan kerjasama tim. 
6. Hasil penelitian ini diharapkan dapat ditindak lanjuti oleh para peneliti lain, sehingga dapat lebih banyak lagi informasi yang didapatkan mengenai faktor-faktor dominan yang memberikan kontribusi terhadap peningkatan efektivitas kerja karyawan.

\section{REFERENSI}

Djamarah, Syaiful B. (2014). Pola Asuh Orang Tua dan Anak Dalam Keluarga: Upaya Membangun Citra Membentuk Pribadi Anak. Jakarta: RIneka Cipta.

Hasibuan, Malayu S. P. (2011). Manajemen Sumber Daya Manusia, Edisi Revisi. Jakarta: Bumi Aksara.

Hidayat. (2013). Pengaruh kepemimpinan terhadap komunikasi, kepuasan kerja, dan komitmen organisasi pada industri perbankan. Makara Seri Sosial Humaninora, 17(1), 19-32. DOI: 10.7454/mssh.v17i1.1799.

Hidayat, D. (2012). Komunikasi Antarpribadi dan Medianya. Yogyakarta: Graha Ilmu.

Komala, L. (2009). Ilmu Komunikasi Perspektif, Proses, dan Konteks. Bandung: Wisya Padjajaran.

Manopo. (2014). Peran Komunikasi Organisasi Dalam Membentuk Efektivitas Kerja Karyawan CV.Magnum Sign And Print Advertising Samarinda. eJournal Imu Komunikasi, 2014, 2 (3): 357-372

Sangaji, Etta M. dan Sopiah. (2010). Metodologi Penelitian. Yogyakarta: ANDI.

Siagian P Sondang. (2011). Manajemen sumber daya manusia. Jakarta: Bumi Aksara.

Soedibjo Bambang. (2013). Pengantar Metode Penelitian. Bandung: Universitas Nasional Pasim.

Sugiyono. (2010). Metode Penelitian Pendidikan Pendekatan Kuantitatif, kualitatif, dan R\&D. Bandung: Alfabeta.
Syafiie, Kencana, Inu, (2011). Manajemen Pemerintahan. Jakarta: Pustaka Reka Cipta

Wijono, S. (2012). Psikologi Industri dan Organisasi. Jakarta: Kencana. 
